\title{
Gender, Race and the Colonial Archive. Sexualized Exoticism and Gendered Racism in Contemporary Italy
}

\author{
Gaia Givliani \\ University of Padova; University of Coimbra
}

My article focuses on particular forms of exoticizing discursive practices produced and reproduced in Italy through the most popular and transgenerational media. Three television shows will be taken into consideration: Licia Colò's Alle falde del Kilimangiaro, Bruno Vespa's Porta a porta, and Alfonso Signorini's Kalispéra!. The latter two are particularly well-known for their coverage of Berlusconi's sex scandal involving the Italian-Moroccan under-age Karima el Mahroug alias Ruby 'Rubacuori'. Alle falde del Kilimangiaro will be contrasted with the ferocious attacks in the media (video and newspaper) by a number of political forces and cultural opinion makers against former Italian Minister for Integration Cécile Kyenge (2013). This discussion will also analyze the discursive strategies employed by both El Mahroug and Kyenge against the exotizing and openly inferiorizing discourses built around them.

KEYWORDS TV exoticism, race, gender, Alle falde del Kilimangiaro, Kalispéra!, Porta a porta.

My article focuses on particular forms of exoticizing discursive practices produced and reproduced in Italy through the most popular and transgenerational media. My aim is to reveal the persistence of a (post-)colonial archive and its reactualization and functionalization in contemporary Italy, within a discourse that tends to construct acceptable Otherness as an orientalized, harmless, silenced, and distanced object of televisual touristic pleasure, and reduce black female social actors to objects of desire/abjection. ${ }^{\mathrm{I}}$ The colonial archive's actualization occurs via a visual construction of the postcolonial racialized Other that alternates the contextualized rearticulation of the 'figures of race'

' Stuart Hall, 'The Spectacle of the "Other", in Representation: Cultural Representations and Signifying Practices, ed. by Stuart Hall (Milton Keynes: Open University Press, I997), pp. 223-90. 
of the 'good,' welcoming, reassuring savage (in the case of the touristic encounter) with those of the infantilized little brown girl to-be-saved, the Mammy, the Jezebel and the Sapphire (in the case of Black Italian women). ${ }^{2}$ This visual construction is driven by that what Frantz Fanon called the white gaze. I argue (following Fatimah Tobing Rony), that in Italy the white gaze has an anthropophagic posture which turns it into a 'scopic regime' that, while producing some subjects as racialized, includes them within the 'colour line' that marks the boundaries of the imagined space of whiteness. ${ }^{3}$ To be included within the imagined (racialized) community of the Nation, these subjects need to be transformed in appropriable objects. The good savage, the little brown victim, as well as the Mammy are thus deployed to contain the 'unmasterable' Jezebel and Sapphire, to reduce them to subalternity and eventually preserve white hegemony. In contemporary Italy, racialized femininities are constructed in slightly different ways from racialized masculinities. ${ }^{4} \mathrm{My}$ interest here is to extend my most recent work on the rearticulations of exoticized and abject female blackness in visual texts produced between the I970s and 20IOs. ${ }^{5}$

Three television shows will be taken into consideration: Alle falde del Kilimangiaro, the most famous and long-running afternoon live television travel show for families, hosted by Licia Colò until 20I3, and two other popular shows, Bruno Vespa's Porta a porta, and Alfonso Signorini's Kalispéra!. ${ }^{6}$ These two shows are particularly well-known for their coverage of Berlusconi's sex scandals — related mostly to his infidelity to former wife Veronica Lario, his relationships with escorts, and the sex parties held in his villa in the Lombard town of Arcore with young women (some of them under-age). One of the most famous scandals involved the Italian-Moroccan under-age Karima el Mahroug alias Ruby 'Rubacuori'.

The aim of the article is to uncover the orientalism and exoticism of most popular cultural products on this topic. It also aims to reveal how apparently harmless exoticizing discourses such as those of Alle falde del Kilimangiaro produce highly inferiorizing and

\footnotetext{
${ }^{2}$ The term 'figures of race' refers to recurrent racial and gender constructions sedimented locally and transnationally in colonial and postcolonial history and culture. Gayatri Chakravarty Spivak, 'Can the Subaltern Speak?', Colonial Discourse and Post-Colonial Theory: A Reader, ed. by Patrick Williams and Laura Chrisman (Hemel Hempstead: Harvester, 1993 repr.), pp. 66-III; Jeanelle Hobson, Venus in the Dark: Blackness and Beauty in Popular Culture (London-New York: Routledge, 2005).

${ }_{3}^{3}$ Frantz Fanon, Peau noire, masques blanches (Paris: Seuil, I952), pp. II8-I9; Fatimah Tobing Rony, The Third Eye. Race, Cinema, and Ethnographic Spectacle (Durham: Duke University Press, 1996); William E.B. Du Bois, The Souls of Black Folk (Penguin: New York, I903; repr. 1996).

${ }^{4}$ In previous works I have focused on constructions of male blackness, gendered stereotypes of 'Chinese-ness', and of Muslim masculinities. See respectively Gaia Giuliani, 'L'italiano negro. La bianchezza degli italiani, dall'Unità al Fascismo', in Bianco e nero. Storia dell'identità razziale degli italiani, Gaia Giuliani, Cristina Lombardi-Diop (Firenze: Le Monnier; Milano: Mondadori Education, 20I3), pp. 2I-66; 'Non ci sono italiani negri. Il colore legittimo nell'Italia contemporanea', in 'La sottile linea bianca', special issue of Studi culturali ed. by Gaia Giuliani, 2 (2013), pp. 254-67; 'L'Italiano negro. The Politics of Colour in Early 20th Century Italy', Interventions. Journal of Postcolonial studies, 4.I6 (20I4), pp. 572-87; 'La zona d'ombra. Genere, agency e bianchezza nell'Italia contemporanea', Subalternità italiane. Percorsi di ricerca tra letteratura e storia, ed. by Valeria Deplano, Lorenzo Mari and Gabriele Proglio (Roma: Aracne, 20I4), pp. 223-46; and Zombie, alieni e mutanti. Le paure dall'II settembre a oggi (Firenze: Le Monnier; Milano: Mondadori Education, 20I6).

5 Gaia Giuliani, 'La razza fuoristrada. Veneri nere tra memoria coloniale e orizzonti globali', Visualità e razza, ed. by Elisa Bordin and Stefano Bosco (Verona: Ombre corte, 20I6, forthcoming).

${ }^{6}$ Alle Falde del Kilimangiaro (I999-2013) hosted by Licia Colò, written by Licia Colò, Vincenzo Arnone, Giovanna Ciorciolini, Manuela Monni and Mariella Salvi, directed by Andrea Dorigo; Kalispéra! (Italy, 20ı-20ıг, Canale 5) hosted by Alfonso Signorini, directed by Lele Biscucci. Porta a porta (Italy, I996-, Rai I) hosted by Bruno Vespa, directed by Marco Aleotti.
} 
sexualizing narratives. Alle falde del Kilimangiaro will be contrasted with the ferocious attacks in the media (video and newspaper coverage will be scrutinized) by a number of political forces and cultural opinion makers against former Italian Minister for Integration, Cécile Kyenge (20I3). Her institutional response in the media will be also explored. This discussion aims to analyze, on the one hand, the articulations of milder exoticizing and openly inferiorizing discourses and, on the other hand, the discursive strategies employed by both El Mahroug and Kyenge.

Through an intersectional approach to cultural products within a Cultural and Postcolonial Studies' analytical framework, my article will focus on the intersections of race, gender, cultural, and regional belonging, and class representations in the visual reproduction of stereotypical Others. ${ }^{7}$

Analyzing the visual imaginary of Italian travelers as constructed by television's most famous and long-lasting shows represents a mapping of the symbolic materials that make up current discourses on cultural/phenotypical diversity and sexuality. This analysis will bring to light what kind of 'regimes of (racist) truth' the serial repetition of these discourses enables. ${ }^{8}$ Popular shows like Alle falde del Kilimangiaro deserve a broader analysis within a tradition of cinema and television productions that democratize the colonial voyeur gaze after the end of the Italian empire. ${ }^{9}$ In the current analysis, these shows are examined with an eye to the important role they play in normalizing a number of discursive (post)colonial inferiorizing practices. Alle falde del Kilimangiaro offers its Italian audience an idealized idea of globalized working and middle class travellers and voyeurs who have been purged of past colonial sins and, as such, can enjoy a post-colonial (cleansed of colonial violence) desire of appropriating the Other's authenticity. ${ }^{\text {Io }}$

Licia Colò's program is particularly important for the analysis of the visual representation of El Mahroug and Kyenge. It reveals better than other similar television shows the easy circulation and reproduction of the post-colonial image of the 'good savage' who, as such, is meant to remain silent and strange. In contrast, El Mahroug and Kyenge are speaking subjects, black but Italian. This allows a construction of them as dangerously abject, that is as 'space invading' ${ }^{\text {II }}$ gendered and racialized subjects disrupting a self-reflexive, male, heteronormative, and white idea of the nation.

The deconstruction of Colò's show will be carried out through the theoretical frameworks provided by cultural anthropology, Italian and international colonial and postcolonial feminist studies, black and critical whiteness studies, cultural studies and political

\footnotetext{
${ }^{7}$ My theoretical framework is based on studies of race, gender, and sexuality, history of photography's exploration of representations of racialized othernes in colonial and post-colonial contexts, Frantz Fanon's work, Stuart Hall's work on race and visuality, and the research on beauty and race within beauty studies [see for instance the 2006 special issue of Feminist Theory, 7.2); and more specifically in AA.VV., The Fact of Blackness: Frantz Fanon and Visual Representation, Institute of Contemporary Arts of London, London, I999. See, amongst others, Ann Laura Stoler, Carnal Knowledge and Imperial Power: Race and the Intimate in Colonial Rule (Berkeley: University of California Press, 2002); Anne McClintock, Imperial Leather: Race, Gender and Sexuality in the Colonial Contest (New York: Routledge, I995); Sara Ahmed, 'A Phenomenology of Whiteness', Feminist Theory, 8 (2007), I49-68; Judith Butler, 'Engendered/Endangered: Schematic Racism and White Paranoia', Reading Rodney King, Reading Urban Uprising, ed. by Robert Gooding-Williams (New York-London: Routledge, I993), pp. 15-22; Hobson, Venus in the Dark. ${ }^{8} \mathrm{John}$ Tagg, The Burden of Representation: Essays on Photographies and Histories (Amherst: University of Massachusetts Press, I988); Judith Butler, 'Engendered/Endangered'.

9 See Giuliani, ed., Il colore della nazione.

ro See Giuliani, 'La razza fuoristrada'.

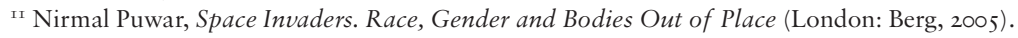


philosophy. Through a feminist analysis of Italian television imaginaries, I will analyze the tension between the screen life of stereotypes, the real life of an exoticized subject on screen, and their role in hegemonic discourses on race, whiteness, and gender. This analysis not only provides an explanation of the hegemonic purport of particular discursive constructions, but also reveals the possibility, in the cases I discuss here, of an agency against or alongside them according to the exoticized subject's intersectional position. ${ }^{\mathrm{I} 2}$ Building on theoretical insights by postcolonial and black feminists, my article will focus on the subalterns' capacity to disrupt particular exoticizing images, even when these images and discourses silence and neutralize them, as well as their complicity with/ resilience against them.

Alle falde del Kilimangiaro (from now AFDK) has been produced and broadcast for more than fourteen years, targeting an audience mostly aged between 20 and 6o. It focuses on travel and the exotic experience of the encounter with 'different' cultures and environments, within the frame of both travel stories recounted by the travellers themselves and amateur documentaries. Since the beginning, its originality lay in the involvement of its television audience - absent in more traditional and very popular Italian programs on travel (i.e. Sereno variabile by Osvaldo Bevilacqua) ${ }^{\mathrm{I} 3}$ - through visual products documenting their trip. Lately it has competed with similar cultural products, some of them - the more innovative and trendy ones — imported and broadcast mostly by corporate television channels. ${ }^{\mathrm{I}}{ }^{\mathrm{a}}$

Until 2013, AFDK was composed of a set of features including a documentary report on a tour made by the host, Licia Colò; an award for the best amateur video submitted by the audience and selected by the programme's staff; and a short live musical show by the so-called multicultural Kilimangiaro band. The latter was often supporting a local band invited to perform in the studio and representing world culture. This was the core segment of the programme. For many seasons, the programme included a quiz on different cultures and peoples. In some cases, this quiz regarded a typical or guest in typical costume: his/her welcome message was used to present aspects of that particular culture. In the 20I2-I3 season, the quiz was called 'Dove siamo?' and involved viewers voting by phone. This element of AFDK's format introduces immediately the asymmetry and voyeurism that characterizes the programme, where no substantial historical or political framework is provided, nor a true contact between tourists and locals, let alone a critical understanding of that contact itself.

Asymmetry refers here to the relationship between the tourist/expert/programme's host narrative and the voice of the locals encountered during the trip. It springs from the fact

\footnotetext{
I2 Kimberlé W. Crenshaw, 'Mapping the Margins: Intersectionality, Identity Politics, and Violence against Women of Color', Stanford Law Review, 6 (I99I), I24I-99; Nira Yuval-Davis, 'Intersectionality and Feminist Politics', European Journal of Women's Studies, (3) 2006, 193-209.

${ }^{13}$ Broadcast on Rai 2 from 1977.

${ }^{14}$ The TripAdvisor's forum credits AFDK as one of the unavoidable sources for travelling and touristic insights. Amongst its competitors we can find No reservation (UK) by English writer Anthony Bourdain, broadcast from 20II, Rai 5, Carnet de voyage (France, Rai 5), Lonely planet (Italy, 200I-, Rai 5), Dreams road (Italy, 2004-, first Rai 5, then Rai I), Donna avventura (Italy, 2000-, Rete 4), Linea Blu (Italy, I993-, Rai I), Stella del Sud (Italy, 2008-2009, Rai I), Turisti per caso (Italy, I99I-200I e 2006, Rai I) hosted by Susy Blady and Roberto Roversi, which is one of the oldest competitors of AFDK acording to bloggers and forums like TripAdvisor, Ulisse - il piacere della scoperta hosted by Alberto Angela (Italy, 2000-, Rai 3), Marcopolotv (Italy, I997-, Sky channel dedicted to tourism and explorations), Dovetv (Italy, 2010-, Sky channel dedicated to holidays and tourism), Pechino express, a reality show hosted by Emanuele Filiberto Savoia (Italy, 20I2, Rai 2).
} 
that the only viewpoint represented is that of the tourist. His/her gaze forges, as much as in the grand tour tradition, Europe's imagination and its knowledge of the (post) colonial, internally-colonial, gendered, and racialized Other. ${ }^{15}$ Clearly, it is not a dialogue between equals, and the voice of the locals that the viewer can hear is largely an accessory to the film's narrative, and thus the voice of a necessarily diminished subjectivity.

The apparent protagonist is the Bauman's 'global tourist' who is white, Western, and primarily heterosexual; the alleged core of the programme is the striving for a so-called authentic experience. Zygmunt Bauman has described this particular type of tourist as imbibed by the explorative/appropriative post-colonial approach which is driven by its economic, cultural, and social privilege. ${ }^{16} \mathrm{His} /$ her tourism generally endorses some of the best intentions. As a spectator and a traveler, her/his voyeurism towards the program's exoticized subjects is not characterized by a lascivious attitude. Rather, it demonstrates political correctness and bourgeois containment, insofar as it treats the people and places that $\mathrm{s} /$ he encounters in her/his travels as harmless, silenced, and distanced objects of tourist pleasure.

The tourist in AFDK apparently does not take advantage of the globalized mass tourism industry, including organized tours, cruises and staying in luxury hotels, nor the structures of global amusement, including clubbing and cheap prostitution. His/her 'appropriation and domestication of Otherness' is presented as free from the many epistemological consequences of the entanglements between the production of knowledge about the Other and colonial dominance. ${ }^{17}$ It is an appropriation pretended as private, intrinsically self-conscious and critical of a certain model of mass tourism.

What I have called elsewhere symbolic anthropophagy, that is, the most relevant dynamic of Italian (hetero referential) racism, is here apparently reduced to the sole 'scopic regime'. ${ }^{18}$ What AFDK reveals is both the permanence of racist and colonial elements and discursive practices in Italian mass culture, and their effectiveness in shaping the nation's gaze on itself and its Others.

I see Italian racial identity as mostly the result of a hetero-referential racism intended as a system of racialization that is centred on the Other. A fundamental trait of such a system is the occultation of the Self, of which people have no spontaneous awareness. ${ }^{\text {I9 }}$ It is the assignment of a specific colour (from a darker nuance than white, to black) to the internal/colonial and postcolonial Other that produces — implicitly — the racial identity of the Self. Colette Guillaumin's categories explain the intrinsic peculiarity of a construction of the Self 'by contrast', as argued by Michele Nani. ${ }^{20}$ This construction

${ }^{15}$ See Edward Said, Orientalism (New York: Vintage, I979); Culture and Imperialism (New York: Kopf, I993); Homi Bhabha, The Location of Culture (London-New York: Routledge, I994); Nicholas Thomas, Colonialism's Culture. Anthropology, Travel, and Government (Princeton: Princeton University Press, I994).

${ }^{16}$ Zygmunt Bauman, Globalization: The Human Consequences (New York: Columbia University Press, I998).

${ }^{17}$ Sara Ahmed, Differences that Matter: Feminist Theory and Postmodernism (Cambridge: Cambridge University Press, I998).

${ }^{18}$ On symbolic anthropophagism see Giuliani (ed.), Il colore della nazione, Giuliani, 'Mediterraneità e bianchezza Il razzismo italiano tra fascismo e articolazioni contemporanee (I86I-20I5)', Iperstoria, 6 (20I5 b), pp. I67-82. On the concept of hetero-referential racism see Colette Guillaumin, 'Caractères spécifiques de l'ideologie raciste', Cahiers Internationaux de sociologie, 53 (I972), 247-74. On the concept of 'scopic regime' see Tobing Rony.

I9 Ruth Frankenberg, 'The Mirage of an Unmarked Whiteness', The Making and Un-Making of Whiteness, ed. by Barbara B. Rasmussen, Eric Klinenberg, Irene Nexica, Matt Wray (Durham-London: Duke University Press, 200I), pp. 72-96.

${ }^{20}$ Michele Nani, Ai confini della nazione. Stampa e razzismo nell'Italia di fine Ottocento (Roma: Carocci, 2006). 
continued from Liberal Italy to Fascism, and it operated in racially unifying a nation by opposition to its internal (the Southerner, the Roma/Sinti, the Jewish, as well as a number of gendered and sexualized subjects, from women to queer and transgender/transexual persons) and external abjects (the colonized). This construction correlates with an idea of historical/cultural common features (Italians' European Mediterranean-ness), which in post-fascist Italy is only apparently de-racialized.

The correlation between hetero-referential racism and symbolic anthropophagy as one of the legacies of colonial and enslaved commodification of the (mostly female) racialized body - turns the body of racialized gendered subjects into either an exotic and marketable object of pleasure or a source of abjection. I called this move towards the objectified, racialized, gendered subject as anthropophagic, borrowing the term from Decolonial Studies in Latin America and from Indigenous Studies in the Pacific and Australia, where it refers to the 'cannibalistic approach' respectively of Spanish and British settler colonialisms.

In my discussion, I read this argument through the lenses of 'symbolic cannibalism' as articulated by black feminism, and I use it to represent a digestive model of racialized citizenship. This kind of citizenship transforms phenotypic differences into nutrients for the Italian body politic that assimilates them, neutralizing their cultural differences and their political subjectivities. According to the anthropophagic model of the Italian nation, a number of subjects can be assimilated insofar as they are considered absorbable, because silent, objectified bodies of desire, who confirm to the normativized subject's whiteness. ${ }^{2 \mathrm{I}}$

The global tourist's appropriative/cannibalistic approach is confirmed and enhanced by the location - AFDK's studio - that functions as a memory drawer of the Others' lives, captured in amateur narratives of travelling. The studio converts the private into the commercialized and thus public sphere: it makes amateur experiences recorded in video the subject matter of entertainment, according to the programme's scheme, language, and content.

Besides being cognitive/appropriative, one of the basic rules of the programme is politeness. The gaze/experience of the global tourist (purged of the colonial sin), who shows his/her own video during the programme, is aligned with that of the host, Licia Colò, whose report occupies a large section of each program. Both foster representations of the Other and the Self that are never excessive, vulgar, or traumatic. No conflict or 'uncanniness' are allowed to enter the narrative. The imagined life of the Other is constructed and reproduced as cleansed of any unpalatable oddity and threatening conflictual subjectivity. This constitutes a contrast with a colonial past where oddity and conflictual subjectivity would have justified long-lasting colonial occupation.

In the contemporary television program, the cleansed appropriation of the Other is a temporary experience, abstracted from historical time and place. The outlandishness of the touristic encounter with the Other is epitomized by the amateur video on Egypt opening the programme broadcast on I6 December 20I2: this spectacularizes Egypt's architectural and natural beauties with no mention of the political context, characterized by the destitution of former plenipotentiary president Mubarak and the occupation of Tahrir square in Cairo by local protesters in their thousands. The only warning is about 'hot areas'.

${ }^{21}$ See in particular Giuliani, 'La razza fuoristrada' 
AFDK thus seems to espouse a purged exoticism that silences challenging cultural differences for the amusement of its audience, and avoids an openly inferiorizing, racializing or despising language in its depiction of Otherness. The music/dance sequence, a highly essentialized example of a supposedly crystallized 'remote culture', functions as an intermezzo of diversity for standardized voyeurs. As Colò herself states after each of these live performances, what is shown is 'extremely different from our culture', ${ }^{22}$ but nonetheless understandable, acceptable and pleasant.

The reduced complexity of what is presented as diverse is functional to a standardized self-identification of the viewers with the recorded experience: the gaze of the tourists in the studio - who are $99 \%$ white, heterosexual, middle class, educated, or, if not, with significant cultural capital — needs to become the audience's eye. This potential correspondence allows the programme's narrative to involve the viewers into a project of voyeuristic self-projection. This self-identification evidently excludes the locals. The authoriality of the experience — in a traditionally Cartesian mode — is always assigned to the traveler, and this is openly confirmed by AFDK. Self-identification triggers the audience's curiosity, attention, and desire for a similar knowledge and appropriation of contexts and people, who remain inanimate objects of desire. The success of this nonviolent, uncritically appropriative self-identification is demonstrated by the programme's popularity in terms of audience and longevity.

In the last fifteen years, many similar television shows widely produced and broadcast have built a different type of self-identification, less focused on authenticity and more directed towards locals' agency and the possibility of a shared experience with them. In AFDK, exoticism remains very much the result of a traditional narrative of cultural/natural crystallized diversities, as if many layers of global connections (like global migrations and trade, often exploitative and conflictual) have not created the basis for encounter and exchange. The show remains trapped within a deeply stereotypical and agency-deprived figuration of Otherness, embodied by people acting as anonymous and inanimate parts of the landscape.

The locals become animated - but never individuals, always representative of the Other's authenticity - only when they come in contact with Bauman's tourist, and function as a tool for the latter's search for touristic pleasure. They remain anonymous also when they perform in the studio: the performance script reproduces a set of standardized/marketable signs of Otherness, today commercialized by the global industry of cultural products (capoeira and samba for Brazil, traditional dances in traditional attire for Nigeria, djambé session for Senegal, etc.). Quizzes perform the same role: they invite competitors to guess the so-called ethnic belonging of a series of cultural elements through a number of highly commodified and thus recognizable clues (tango for Argentinians, skin-colour/eye shape and traditional clothes for China). The amateur video-competition also operates on the principle of the further away the better. Hence it is not so much the beauty of a video - whether related to the quality of its style and

\footnotetext{
${ }^{22}$ See for instance, the host's commentaries on the short-shows by Ramona Badescu and a Cuban dance group in 2008, http://www.youtube.com/watch?v=XIwfGOr 3 NcE [accessed II July 20I6]; by Tamburi di Goree (Senegal)

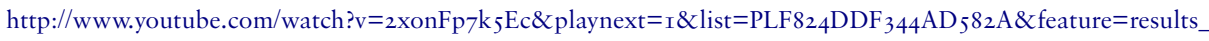
main [accessed II July 20I6]; by Africa Creation Senegal Fashion Show, http://www.youtube.com/watch?v=2ArFCwVb_xQ [accessed II July 20I6]; and in 2010 by the Georgian national ballet, http://www.youtube.com/ watch?v=TwvBaTuFKmw [accessed II July 20I6].
} 
editing, a path-breaking story, or the originality of the trip's organization - that leads to it success, but the symbolic/material distance between Italy/Europe/the West and the exotic locale: Japan wins over France (2002), Uzbekistan over Lisbon (2013).

The familiarization of the Other's culture and society corresponds to its domestication and produces a benevolent objectivization, perfectly responding to the needs of a television programme for families. The orientation of AFDK can be defined as neo-Victorian and petit-bourgeois, as it is de-historicized, de-traumatized, de-sexualized, devoid of conflicts, sensitive to racial, class, and gender divides in so far as the awareness of them does not challenge their entertainment value. The colonial past is never mentioned, neither are international, national, and local responsibilities for specific poor living conditions.

Daily life's complexities, contradictions, resistances and struggles cannot enter the semantic/physical space of the programme. Men and women, the bodies of older people and children are sufficiently humanized to serve the tourist's search of self-indulgent empathy with the diverse. But as mentioned before, this experience needs to be kept gentle, distanced, unproblematic and, most importantly, temporary: the Others who enter the scene smile, do what they are requested to do, leave and do not come back again, as if behind W.E.B. Du Bois' transparent glass that makes them mere transitory presences, their lives inscrutable and their voices inaudible. The glass (the television screen) creates indeed what Jennifer Stoaver-Ackerman has called 'the Duboizian sonic colour line':

In essence, the sonic color-line is a socially constructed boundary where racial difference is produced, coded, and policed. It both insulates and preserves the logic of white supremacy, while sounding out the perimeters that supremacist thought places on black freedom, identity, mobility, and citizenship. ${ }^{23}$

In the context of $A F D K$, the highly coded and policed performance behind the television screen makes the performers the perfect animated, but silenced backdrop for touristic pleasure. Performers are mere signifiers of a pre-conceptual idea of a different culture and as such they are unable to represent something that fails to match the predictable and familiar.

An important role in this softening of the petit-bourgeois exotic experience of the Other is enacted by the programme's host herself, whose feminine touch - benevolent, familiar, and juvenile, although she is in her fifties - appears to provide a maternal guide through the Others' lives and places. She guides the viewers into the Other's life through the exotic experiences of the invited tourists. In fact, every story is mediated and preceded by a short commentary from the host. The introduction/mediation tailors the cultural product (the amateur video, the music/performance show, the humanitarian advertisement, etc.) to the audience, which is imagined as in need of a guide and an interpreter even for its own adventures. This process of appropriation and neutralization of the voice of the tourists and performers - which is typical of this particular television format - is coordinated by the programme's technical staff, who cut and edit each video, inserting further stored images and often a voice-over. ${ }^{24}$

${ }^{23}$ William E.B. Du Bois, The Dusk of Dawn (1940) (New York: Transaction Publishers, I984); Jennifer StoeverAckerman, 'W.E.B. Du Bois e la linea del colore sonora', Studi culturali, I (20I3), 7 I-88 (p. 72).

${ }^{24}$ In 20I4, Licia Colò was fired, apparently because of disagreements with Rai3 director Andrea Vianello (20I3-20I6). Since then, the programme has been led by Camila Raznovich and has included new and old sections within a deeply renovated structure and design. The programme does not include performances 'of authentic Otherness': it is rather more focused on videos produced by the programme's staff itself. 
The contrast between the baroque exoticism of AFDK and the media's brutal figuration of Kharima 'Ruby' El Mahroug is quite evident. This is due to a number of important factors: the different audience targeted by the television programmes, the different positions occupied by the exoticized object (that is, his/her cultural capital, cultural distance, territorial proximity-distance, access to privilege, gender, under/hyper-sexualization and different degrees of eroticization), and, importantly, the target for self-identification. Most importantly, El Mahroug classifies herself as Italian and Moroccan, a condition that erases the safe distance that $A F D K$ places between the prospective audience and the racialized objects of touristic voyeurism.

In the case of Karima El Mahroug performing in the shows of Bruno Vespa and Signorini, the representation of the racialized/exoticized, gendered Other is hyper-sexualized as much as the audience's gaze is asked to identify with ideas of virility, sexuality, masculinity, femininity, eroticism, and exoticism that are epitomized by Silvio Berlusconi's aesthetics, and that are ingrained in a very important Italian cultural tradition. I am referring to the cultural tradition that connects discourses on Italian (Roman and Mediterranean) virility with an inclusive - anthropophagic - idea of male and female sexuality. ${ }^{25}$ This combination includes the female body within the space of domesticity as an object of male sexual desire (symbolic anthropophagy), object which functions as a vehicle of both social inclusion (through marriage) and exclusion (through concubinage, adultery or prostitution).

In the case of the media coverage of 'Ruby-gate', this peculiar inclusion of the female body within a hegemonically male public space drives self-identification towards the figure of Berlusconi, giving room to a self-projection onto an idea of masculinity that is determined by class, heteronormativity, and racialization. These two television programmes do not take explicit advantage of the asymmetry between the sexual tourist and its object of desire: according to the narrative of the case they project, Ruby is not a victim; neither a poor woman who did what she did out of necessity, nor a person whose sexual services were commodified in any way.

On the contrary, Ruby is represented as profiting from the Italian good guy, ${ }^{26}$ precisely the representative of the myth of 'italiani brava gente', that is those soldiers and civilians who in the hegemonic discourse on our (male) colonial enterprise in the African Horn are seen as benefactors of many 'morette coloniali' (colonized young black female girls taken as 'madame' - that is temporary wives — or prostitutes). This narrative concealed for many decades the inequality existing between white heterosexual men of power and ordinary young and beautiful brown/black women within colonial and postcolonial contexts, structured by highly sexualized power relations, and governed by white privilege. ${ }^{27}$ This narrative still hides the different position occupied by El Mahroug in the power

\footnotetext{
${ }^{25}$ See Giuliani, 'L’italiano negro. La bianchezza degli italiani', pp. 47-56.

${ }^{26}$ See www.repubblica.it/politica/20Io/ro/29/news/ruby-8560584/ [accessed II July 20I5].

${ }^{27}$ See Giovanna Campassi, 'Il madamato in A.O: relazioni tra italiani e indigene come forma di aggressione coloniale', Miscellanea di Storia delle Esplorazioni, XII (1987), 219-60; Giulia Barrera, Dangerous Liaisons. Colonial Concubinage in Eritrea, I890-I94I (Evanstone: Northwestern University Press, 1996); Barbara Sòrgoni, Parole e corpi. Antropologia, discorso giuridico e politiche sessuali interrazziali nella colonia Eritrea, I890-I94I (Napoli: Liguori, I998); Vincenza Perilli, 'L'analogia imperfetta. Sessismo, razzismo e femminismi tra Italia, Francia e Stati Uniti', Zapruder, I3 (2007), 9-25; Giulietta Stefani, Colonia per maschi. Italiani in Africa Orientale: una storia di genere (Verona: Ombre Corte, 2007); Barbara Spadaro, Una colonia italiana: incontri, memorie e rappresentazioni tra Italia e Libia (Firenze: Le Monnier; Milano: Mondadori Education, 2013).
} 
relation with former president Berlusconi, and simply blames her for her own Jezebel nature - that is, her natural inclination, established through one of the reiterated 'figures' of the black woman, to get her (male, white) lovers in trouble.

The obvious difference between the AFDK tourist's de-eroticized anthropophagy and this more openly erotic anthropophagy derives from the position occupied by male (hetero) sexual desire, which is evaded in Licia Colò's neo-Victorian, petit-bourgeois programme and appealed to in those of Vespa and Signorini. In AFDK, the male (hetero) sexual desire is concealed where the colonial experience of the Other is reduced to something purely intellectual, reasonably tasteful, morally contained, and strictly familiar. In Vespa's and Signorini's programmes, the male (hetero) sexual desire is reclaimed, instead, as an accepted intrinsic element of Italian identity. The hyper-sexualized gaze triggered by these programs is seen as a direct emanation of the racialized mythology of Italian masculinity. This mythology combines ideas of (heteronormative) virility, unbounded love for pleasure, and unlimited passion. ${ }^{28}$ This mythology — which can be traced back to Fascism ${ }^{29}$ — turns the female body into an object, and female sexual desire into a residual, secondary effect of male sexual desire. In the case of the hyper-sexuality assigned to Ruby, this mythology distinguishes her from over-sexualized Italian (white) women, for the lack of modesty, moral and social concerns that are attached to Jezebels. Her desire exceeds that allowed to women and as such her independence and agency are dangerous and immoral.

Unlike Signorini, Vespa treats the case with a sort of surgical approach that seems to anesthetize any sexual desire towards Ruby. However, Vespa's investigation through facts and central characters reiterates indecent details which enhance the audience's curiosity. He does not focus overtly on the fact that Karima El Mahroug is not white, but this covert aspect tickles the audience's imagination, contributing to the attention paid to the exuberant and 'brown-tanned' body of the barely adult girl. Vespa's construction of Karima El Mahroug as Ruby does not draw directly on colonial racist narratives of virgin lands - as well as virgin women — ready to be penetrated. ${ }^{30}$ This would have dismissed the feral, aggressive, active sexual subjectivity of Ruby.

Again, Ruby is Jezebel, a little, 'unmasterable', animalized sexual object within a 'colonial and multiracial burlesque' (as Berlusconi himself called it), which corresponds to the 'zoo of differences' commodified by the images captured in Berlusconi's television channels. This burlesque must be, like Italian society as a whole, 'multi-ethnic but not multicultural', ${ }^{1}$ and as such, it includes difference-as-beautiful only as a function of

\footnotetext{
${ }^{28}$ See Giuliani ‘L’italiano negro. La bianchezza degli italiani’; 'La razza fuoristrada'.

29 Sandro Bellassai, 'The masculine mystique: antimodernism and virility in fascist Italy', Journal of Modern Italian Studies, Io (2005), 3I4-35; L'invenzione della virilità. Politica e immaginario maschile nell'Italia contemporanea (Roma: Carocci, 20II); Barbara Spackman, Fascist Virilities. Rhetoric, Ideology, and Social Fantasy in Italy (Minneapolis: University of Minnesota Press, 2008).

${ }^{30}$ Beside Stoler and McClintock, see Barbara Sòrgoni, 'La Venere Ottentotta. Un'invenzione antropologica per $\mathrm{La}$ difesa della razza', Il Mondo 3.2 (I995), 366-75.

${ }^{31}$ On Berlusconi and his 'multiracial burlesque' see http://www.ilsole24ore.com/art/notizie/20I2-04-20/berlusconi-travestimenti-gare-burlesque-225736.shtml?uuid=AbASWKRF [accessed II July 20I6]. See also Elisa Giomi, 'Da Drive in alla Makeover Television. Modelli femminili e di rapporto fra i sessi nella tv berlusconiana (e non)', Studi culturali, I (20I2), 3-28. The expression 'zoo of differences' is taken from Alessandra Gribaldo, Giovanna Zapperi, Lo schermo del potere. Femminismo e Regime della visibilità (Verona: Ombre corte, 20I2), pp. 42-45. On Italian society being 'multiracial but not multicultural' see www.corriere.it/Primo_Piano/Politica/2006/Notizie/ Politiche2006/articoli/immigrati.shtml [accessed II July 20I6] and http://www.ilsolez4ore.com/art/SoleOnLine $4 /$ Italia/2009/05/berlusconi-no-italia-multietnica.shtml [accessed II July 20I6].
} 
the manly, white, Italian sexual desire for young, beautiful, and tanned female bodies. Vespa stays with this script, without mentioning Berlusconi's sexual desire for Ruby, as if Ruby was the little brown girl to-be-defended and saved (by Berlusconi himself) from danger and abuse.

Porta a porta is a very successful and long-lasting talk show focusing on ongoing Italian and international political debates, scandals, latest news (especially involving unsolved or complicated murders), and legal cases. It is broadcast late at night from Monday to Thursday and is hosted by former director of the State television channel RaiI (I990-I993), Bruno Vespa, who is also the author of a number of volumes on political and social life in contemporary Italy. Its success and longevity is confirmed by the fact that the stage design and the structure of each programme remain unchanged. Some of the guests enter the show through a big white door, and amongst them are politicians, journalists, lawyers, criminologists, and a range of celebrities.

These characteristics have earned Vespa's show the label the 'salotto degli italiani', where (the most lascivious) facts, events, and debates are spectacularized and made popular. Vespa's closeness to Berlusconi, combined with the programme's peculiar focus and features, make Porta a porta the perfect stage for discussing Berlusconi's sex scandals, and the programme devoted a number of interviews to the scandals. Two of these debates merit closer attention. The first sees Berlusconi discussing his 'paternal and de-sexualized role' towards Ruby (25 May 20II), the second sees former Minister of Education, Maria Stella Gelmini (I7 November 20II), ${ }^{32}$ stand up for the Prime Minister, maintaining his innocence, claiming the illegitimacy of the prosecutions, and condemning the sick obstinacy of the judiciary that uses legal maneuvers to 'unsettle his government'. Ruby is obviously not in the studio, while the then-Prime Minister and his Catholic Minister (Gelmini) are granted plenty of space to undermine any other version of the story that could contest the allure of Berlusconi's paternal interests towards the girl.

I mention these episodes as the framework within which I will try to read the figure of Ruby that was constructed through the interview carried out by Signorini. Signorini interviewed Ruby in an episode of his short-lasting show Kalispéra!. Compared to Vespa's, the talk show Kalispéra! is short and much less ingrained into the daily reproduction of Italian television mass culture. It was broadcast in 20 IO and 20 I I on Canale 5 and focused mostly on Italian tabloids, in line with the professional figure of Signorini himself, one of the most important Italian gossip-hunters from when he was the director of scandal-based journal Panorama in the 9os, and then director of tabloids like Chi and Tv sorrisi e canzoni. Importantly, the show's format was fully dedicated to scandals and 'hot details' of the private lives of Italian VIPs. These details were offered first hand by a showman who has been called, by anthropologist Massimiliano Panarari, the 'grande maestro' of media populism. ${ }^{33}$

Ruby's interview (9 January 20II) was characterized by both moralism, victimization, and a distinctly complacent tone towards the little bad girl. This complacency seals a series of typically colonial narrative elements. ${ }^{34}$ On the one hand, the other 'Arcore girls',

\footnotetext{
${ }^{32}$ See respectively www.youtube.com/watch?v $=$ HolcqljINqE and $w w w . y o u t u b e . c o m / w a t c h ? v=u F X R s M-R V 54$ [accessed II July 20I6].

${ }_{33}$ Massimo Panarari, L'egemonia sottoculturale. Da Gramsci al gossip (Einaudi: Torino, 20Io).

${ }^{34} \mathrm{http}: / /$ www.repubblica.it/politica/20I I/oI/I9/news/1_intervista_di_ruby_a_signorini_a_nove_anni_violentata_dagli_ zii-II 404909/ [accessed II July 20I6].
} 
that is, the young (white) women participating in Berlusconi's hot parties in his Lombard villa, are absolved from their moral and sexual sins in various ways. On the other, Karima, together with Iris Berardi, a Brazilian under-age 'friend' of Berlusconi, are described as upstarts, ready to sell themselves for money and success, ${ }^{35}$ as if this attitude stemmed from the colour of their skin. They resemble a sort of postmodern harem woman who while made subaltern through a power relation that is mastered by an old white man and his friends - seems also quite independent in her pursuit of (sexual) pleasure, glamour, and money. They perform a role that ranges from the concubine to the character of the movie series Emanuelle nera. ${ }^{36}$

Like Ruby, Emanuelle is always pictured as peeped at and peeping - being herself a photographer - in orgiastic scenes occurring in luxury houses. Object and subject of the pornographic gaze, she was nonetheless the conscious medium through which the (male and female) audience could enter the upper-class space of lubricous luxury. Unlike the locals represented in AFDK, Ruby-Emanuelle is not described as stuck in the past, as a defenseless and de-subjectivated object of knowledge: she represents the most desirable and exotic body which she offers to male and female sexual fantasies. She is a sui generis Baumanian 'vagabond'. She is successful, and as such belongs to the space of the tourist, although the fact that she is a woman and she is black limits her capacity to be a global consumer.

Ruby is troublesome because she is the maker of her own destiny and a disturbing agent within a regime of neo-Victorian white morality that would cast her amongst outcasts to be redeemed, or, conversely, amongst sinners to be hidden. Ruby-Emanuelle simply uses the symbolic and active space as best as she can, framed and mediated by the same codes provided by Berlusconi's television imagery. The zoo of differences she is part of provides us with an image of manliness which she consciously engages in and reproduces. She negotiates the (post-) colonial space of a post-modern Josephine Baker who no longer wears the banana skirt, with the tools that the same virile and colonial culture provides for her, reiterating (mimetically) the symbols of her own subordination.

The fact that exoticized female Otherness is solely for the use of virile and Italic desire for young, beautiful, and tanned brown female bodies shines through the figure of the 'multiethnic burlesque'. The multiethnic burlesque is hinted at by all Italian television

35 http://www.mondoreality.com/sara-tommasi-racconta-il-suo-passato-difficile-su-chi/; http://www.blogtaormina. it /2OI2/04/24/minetti-a-berlusconi-amore-della-mia-vita/99529; http://milano.corriere.it $/ \mathrm{milano} /$ notizie/cronaca/I2_ agosto_23/chiara-danese-processo-ruby-minetti-berlusconi-ambra-battilana-miss-valle-aosta-2I II $535336969 . s h t m l$; http://www.lastampa.it/20I2/II/26/italia/cronache/caso-ruby-una-delle-ragazze-di-arcore-berlusconi-ci-chiedeva-pareri-sulla-crisi-fyYPzRyVFWyvLq9Le2EBBL/pagina.html; www.ilfattoquotidiano.it/20I I/o2/o7/iris-berardidalla-scuola-alberghieraai-concorsi-di-bellezza-poi-lincontro-con-lele-mora-e-le-feste-di-arcore/90636/ [all accessed II July 20I6].

${ }^{36}$ Emanuelle nera is an Italian series of soft porn movies of an extremely exotic set, released in the mid-I97os. These Italian movies are inspired by the French series called Emmanuelle, starring Dutch actress Sylvia Kristel as the protagonist, and based on the novel Emmanuelle by Thai-French writer Emmanuelle Arsan (1967). Italian Emanuelle (with a single $\mathrm{m}$ ) is a black photoreporter, starring the Indonesian beauty Laura Gemser. The production had a considerable budget and movies were shot in a number of different countries. They are the result of a crossover between different genres, from erotic to porn, from action to horror. The series started with Emanuelle nera (Italy, 1975) dir. by Albert Thomas (alias Adalberto Albertini), and became very popular with the second Emanuelle nera - Orient reportage (Italy, I976) dir. by Joe D'Amato (Aristide Massaccesi), director of almost all sequels and the real 'creator' of the notorious figure of Emanuelle: a strong and independent woman, sexually proactive, at the centre of wealthy young and old white men of power, and involved in any sort of depraved set and situation. For an extensive analysis of the character of Emanuelle, see Giuliani, 'La razza fuoristrada'. 
programs and online features that covered the so-called 'Ruby-gate'. ${ }^{37}$ Nonetheless, the arena where this hyper-eroticized exoticism takes shape seems to provide more limited but substantial - spaces of subjectivity than the silenced, de-sexualized arena of AFDK. The former, highly exploitative context gives racialized women back their voices, while it constrains these same voices within rigid (paternalistic/moralistic/complacent) parameters and spaces.

Karima is not just Ruby; she escapes the Dubois's silencing glass that neutralizes AFDK's racialized performers: she co-writes and performs her own script. She forges her own authenticity using her limited agency to negotiate her own space of action of future possibilities. Clearly, the level of agency that Ruby can exert in this space depends on the position she takes in relation to power. After the scandal she married a young white Italian man, the father of her baby. An absolute nobody, after whom she went back to be just Karima. This is the main difference with Emanuelle: Ruby is working class and a concubine, while Emanuelle has an upper-class background, is a professional and always a shining protagonist - she does not allow any of her (white) male partners to treat her as a subaltern, financially dependent, private entertainer.

Ruby's body is a 'porno-trope', as in Sonia Sabelli's reading of McClintock: ${ }^{38}$ in any case, she always denied to have been Berlusconi's sexual partner, always refused to be considered as a prostitute and to accuse Berlusconi of (sexual) exploitation. As in colonial times, she let herself be photographed and included in the erotic universe of the white man, obtaining this way her own form of emancipation. ${ }^{39}$ Ruby is therefore not just a victim - paraphrasing Gayatri C. Spivak, 'the brown girl to be saved from the old white lascivious sinner' - or simply complicit with the system, the Jezebel, reproducing her own exploitation, her own material and symbolic silence and symbolic and material subordination. ${ }^{40}$ She is, rather, a contradictory figure, such as those described by Chandra Mohanty: in the act of trying to profit as much as she can from a situation, she reveals her resilience/opportunism. By displaying herself as a fierce defender of her own subaltern role, she also reveals the desirability and popularity of this type of success, within the limited resources provided to women in contemporary Italy.

Ruby contradicts both an idea of herself as a victim and/or as a profiteer. Victimhood has been strongly proposed as the only pathway to self-redemption from self-(sexual) exploitation by two important recent liberal feminist actors. One is the movement $S e$ non ora quando, born in 20I0-II, gathering mostly feminist and non-feminist middle-class petit-bourgeois women; the other is film-maker Lorella Zanardo, whose critique of society is expressed in the famous video Il corpo delle donne (2009). Together with

\footnotetext{
37 See Servizio pubblico (25 October 20I2): www.youtube.com/watch?v=7_gPOabmWTo; Sky.it Tg24: www.youtube. $\mathrm{com} /$ watch?v=6OigAkMqgfo; Repubblicatv (2OII): www.youtube.com/watch?v=svRzk_2wNEc [accessed II July 20I6].

$3^{8}$ Sonia Sabelli, 'L'eredità del colonialismo nelle rappresentazioni contemporanee del corpo femminile nero', Zapruder, 23 (2010), IO6-I5. See also McClintock, p. 22.

39 Giovanna Campassi, Maria Teresa Sega, 'Uomo bianco e donna nera. L'immagine della donna nella fotografia coloniale', Rivista di storia e critica fotografica, 5 (I983), 54-62, Elisa Bini, 'Fonti fotografiche e storia delle donne: la rappresentazione delle donne nere nelle fotografie coloniali italiane', relazione presentata al convegno della Società Italiana per lo Studio della Storia Contemporanea (SISSCO), Lecce, 2003, pp. I6-I7.

$4^{\circ}$ Spivak, p. 92. See Lorella Zanardo, Il corpo delle donne (Italy 2009), Il corpo delle donne (Milano: Feltrinelli, 20Io), Lorenzo Bernini, 'Not in my name. Il corpo osceno del tiranno e la catastrofe della virilità', Filosofia di Berlusconi. L'essere e il nulla nell'Italia del Cavaliere, ed. by Carlo Chiurco (Verona: Ombre corte, 20I0), pp. I5-5I, O. Guaraldo, '(In)significante padrone. Media, sesso e potere', in Chiurco, pp. 97-I28.
} 
victimhood, neo-Victorianism morally condemns women's promiscuity and the exchange of sex for money/success as degrading activities that belittle and commodify women.

In escaping (involuntarily) the fight between the moralizing neo-Victorians and their Jezebel, Ruby plays her residual role by enacting her own redeeming fictional story. She wanted to convert to Christianity and her father punished her for that. She fled, and Berlusconi helped her. Once the scandal had erupted, she found a fiancé, got pregnant, and gave birth to a lovely little girl. The trial called 'Ruby-gate' had started and in two years concluded with her and her benefactor's full acquittal. Her ever-changing statements about her relation with Berlusconi bewildered lawyers and audience, and unsettled the cold and moderate discourse on Otherness provided elsewhere by formats like that of AFDK: she is not the good savage, she stepped loudly into our private and public space playing the bad girl. She is not lovely and she takes money. She does not wear traditional clothes, nor does she conceal her sexual appeal. This does not mean that the hyper-sexualization of Ruby gives her the opportunity for her own individuation and subjectivation. It just opens a possibility to speak, whether or not through the voice of her master.

Imbibed with exoticizing stereotypes, AFDK, Porta a porta and Kalispéra! provide a viewpoint which is necessarily white, heterosexual, and slightly colonial. However, they differ on the gender perspective that underpins the anthropophagic approach they embody: while we can say that the episodes of Signorini's and Vespa's shows express the sexually loaded anthropophagic male colonial gaze, exoticism in AFDK is produced from a feminine viewpoint, somehow an heir of white and conservative feminisms, ${ }^{4 \mathrm{~T}}$ that from colonial times to the present claim a petit-bourgeois, white and heteronormative ideal of women's emancipation..$^{42}$ The latter expresses an anthropophagic approach that consumes to preserve and preserves to consume Otherness.

The narrative strategy in AFDK objectifies racialized men and women, exhibiting them as signifiers of a coded local culture: in order to keep enjoying exoticized objects, it is necessary to keep our experience of them temporary and standardized. In the case of Kalispéra!, the discourse that reduces exoticized women to erotic tools for a white audience, letting them play the (very controlled and commodified) role of the Jezebel bad girls, does not want to preserve anything but the white gaze over the bad (beautiful) girls. In fact, while background actors in AFDK do not enter the private space of our houses and bedrooms, Ruby inhabits our intimacy. She does not live in a remote touristic place, but in our daily life and space.

I will conclude my discussion comparing these two cases with that of former Minister of Integration Cécile Kyenge, object of racist insults by a number of political groups and social networks users. I have maintained elsewhere that the specific racialized identity politics in modern and contemporary Italy is structured around what I have called an anthropophagic approach to racialized and gendered diversity and what I have described as the limit of anthropophagy. The case of Kyenge, in my opinion, exemplifies that limit, within a discursive context that is nurtured by a post-Berlusconian moralizing mainstream culture that constrains public language within a certain political correctness. The latter corresponds to a transition that establishes (relatively) new conceptions of (white) supremacy and hegemony, racialized and gendered power relations that are imagined as radically different from those characterizing Berlusconi's political and cultural phase.

\footnotetext{
${ }^{4 \mathrm{I}}$ See Perilli, 'L'analogia imperfetta', pp. 9-20.

${ }^{42}$ Chandra T. Mohanty, Feminism Without Borders: Decolonizing Theory, Practicing Solidarity (Durham: Duke University Press, 2003), pp. I06-23.
} 
I would describe this cultural phase as grounded on a new 'moral contract', ${ }^{43}$ springing from the neo-Victorian approach of anti-Berlusconian vulgate, a discursive order that claims to be inspired by multicultural political correctness. As such, it does not challenge white privilege, structural sexism and their intersections, but simply ascribes them, when brutally stated, to the Lega Nord and extreme right-wing formations. Neo-Victorianism demonizes the latter, after the end of Berlusconi's government and the far-right's recent separation from the national coalition with his party, as representative of the so-called deep North and populist underbelly.

Since her nomination as Minister for Integration, Kyenge has been constantly insulted by the Lega Nord's representative at the European Parliament, Roberto Calderoli, who compared her to an orangutan - an offence for which he has been legally prosecuted. ${ }^{44}$ The worst insults received by Kyenge followed her statements about the necessity of radically reforming both migrant flows restrictions and the devices that regulated the access to Italian citizenship for migrants and their children, introducing the Ius Soli. Among the episodes of violent protest against the Minister, one was held in Brescia and organized by Lega Nord, Fratelli d'Italia, and Forza Nuova in early 20I4. Following that protest, the Lega Nord's newspaper La Padania published the list of public and institutional events to which Kyenge was invited, encouraging readers and members of right-wing political formations to continue manifesting their dissent. ${ }^{45}$

The media coverage in television news, as well as discussions in talk shows about demonstrations, pickets, and the insults on social networks against the black Minister, made her figure extremely visible. Her brutal racialization, constructed through her animalization, seemed to fix, on the one hand, her body as the boundary of the anthropophagic approach, that is the limit of the absorbability of blackness into the Italian and Mediterranean identity, and, on the other, the racial identity of Italians as white. She is positioned within the traditional polarization between black and white that has been so fundamental to the colonial definition of Italian whiteness.

Kyenge cannot be a representative of Italianità, not just because she is black and female, but also because as such she is not the good savage of AFDK, a cannibalizable silent Other, but a government representative, and insists on speaking on behalf of Italians. Her hated presence, conversely, through what Guillaumin calls hetero-referential racialization, confirms what Italianità is meant to be. The media coverage of the case and the consequent spectacularization of the offences against her in papers and television

\footnotetext{
${ }^{43}$ This 'moral contract' is immediately substantiated by the nomination of a black, upperclass woman as Minister of Intergration, with no money and substantially no power without the ability to change the Bossi-Fini law regulating migration flows. The law maintains the illegality of undocumented alien migration and illegal migrants' detention in Centres for Identification and explusion (CIE) against whose conditions detainees' revolts burst continuously: although Kyenge's was to reform it: www.ilfattoquotidiano.it/2013/05/05/immigrazione-il-neo-ministro-kienge-abrogare-reato-di-clandestinita/58394I/ [accessed II July 20I6]; the Ministry of Interior's new law did not substantially change it: http:/it.blastingnews.com/politica/20I4/oI/parziale-cancellazione-del-reato-di-immigrazione-clandestina-0057507.html [accessed II July 20I6]. From the Italian legislation's viewpoint, migrants' death in the Mediterranean is a reasonable collateral effect of a substantially godd regulating frame: http://www. europaquotidiano.it/20I3/Io/2I/il-funerale-farsa-di-agrigento-lampedusa-beffata/ [accessed II July 20I6]. Kyenge referred also to the necessity to change the jus sanguinins on which citizenship right are grounded, with a jus soli legislation that assigns Italian citizenship to any person born in Italy.

${ }^{44}$ http://milano.repubblica.it/cronaca/20I3/II/o9/news/razzismo_calderoli_a_processo_per_gli_insulti_al_ministro_kyenge-70603269/[accessed II July 20I6].

${ }^{45} \mathrm{http} / /$ www.ilfattoquotidiano.it/20I4/oI/I $/$ kyenge-la-padania-pubblica-lagenda-degli-appuntamenti-del-ministro/84267I/ [accessed II July 20I6].
} 
debates nationwide strengthened the ideological bases of openly racist formations. At the same time, they offered a broader field for self-identification of the audience with an Italian-ness that is white, heteronormative, strongly based on a hyper-sexualization of masculinity and femininity and a wide-spread objectivization of the female body, especially if racialized. Racist insults establish a continuity with pre-republican, colonial and fascist language which is openly denigrating and patronizing. ${ }^{46}$ It is furthermore appropriated by many neo-fascist political groups subscribing to the idea of the AlpinianCeltic descent claimed by racists during the Liberal era, and today transfigured into the discourse of the Lega Nord. 47

The two components woven into the far-right delegitimizing discourse against Kyengeinferiorizing blackness — can also be found in less openly animalizing statements. During an episode of Corrado Formigli's Piazza pulita (I3 January 20I4), 4 $^{8}$ Matteo Salvini, following Calderoli, objectified the figure of Kyenge, judging her not for her institutional role and political orientations but for being 'an ugly, black, middle age woman' (Salvini at Piazza pulita, I3 January 20I4 La7).

As a woman, black, no longer young, not available for sexual exchange and with an institutional investiture, Kyenge is a non-cannibalizable black female subject. She represents an excessive body that cannot be normalized or domesticated within models of femininity and female (racialized) beauty which can serve male, white (hetero) sexual desire and which have been constantly reaffirmed by Italian television since the I980s. ${ }^{49}$ Kyenge has the chubby face of a ya bon-banania: but, unlike those commercial and reassuring figures of French and Belgian colonialism that reached post-fascist Italy with advertisements and cartoons, she cannot be identified as the 'figure of race' of the tamed and subaltern Mammy. ${ }^{50}$

She is neither a black caregiver nor a Jezebel like Ruby. ${ }^{\text {I }}$ She could be seen as a Sapphire (the 'figure of race' of the Angry Black Woman who has a strong and assertive character and competes with men for positions of power) and as a proud, well educated, upper class black woman with natural hair — but she is denied these roles and is simply animalized.

After Calderoli's insults, Minister Kyenge stated that 'Le [sue] parole, non le prendo come un'offesa personale, ma mi rattristano per l'immagine che diamo dell'Italia. Credo che tutte le forze politiche debbano riflettere sull'uso che fanno della comunicazione'. ${ }^{52}$ She reacted tepidly, moderately, and her tone has always been sober and reassuring, as if she

\footnotetext{
${ }^{46}$ See Aaron Gillette, Racial Theories in Fascist Italy (London: Routledge, 2002), Francesco Cassata, Molti, sani e forti. L'eugenetica in Italia (Torino: Bollati Boringhieri, 2006); Silvana Patriarca, Italianità. La costruzione del carattere nazionale (Roma-Bari: Laterza, 20Io); Alberto Maria Banti, Sublime madre nostra. La nazione italiana dal Risorgimento al Fascismo (Roma-Bari: Laterza, 20II); Giuliani and Lombardi-Diop, pp. II7-38.

${ }^{47}$ Francesco Cassata, 'La Difesa della razza'. Politica, ideologia e immagine del razzismo fascista (Torino: Einaudi, 2008).

$4^{8}$ http://www.polisblog.it/post/I94687/piazzapulita-I3-gennaio-20I4-diretta-ospiti [accessed II July 20I6].

${ }^{49}$ Luisella Bolla, Flaminia Cardini, Carne in scatola. La rappresentazione del corpo nella televisione italiana (Roma: Rai-Eri VQPT, I999).

${ }^{5 \circ}$ Cristina Lombardi-Diop, 'Igiene, pulizia, bellezza e razza. La "bianchezza" nella cultura italiana dal Fascismo al dopoguerra', Parlare di razza: La lingua del colore tra Italia e Stati Uniti, ed. by Tatiana Petrovich Njegosh, Anna Scacchi (Verona: Ombre corte, 20I2), pp. 78-96; Vincenza Perilli, “Sesso' e 'razza' al muro. Il sistema sessismo/razzismo in pubblicità', in Specchio delle sue brame, ed. by Laura Corradi (Roma: Ediesse, 20I2), pp. 9I-I26 (II6-I8). ${ }^{51}$ See Sabrina Marchetti, Le ragazze di Asmara (Roma: Ediesse, 20II).

$52 \mathrm{http}: / /$ www.repubblica.it/politica/20I3/07/I 4/news/vedo_il_ministro_kyenge_e_penso_a_un_orango_e_polemica_per_la_frase_del_leghista_calderoli-62945682/ [accessed II July 20I6].
} 
wanted to reinstate her institutional role, her social status (her background is upper class), and her role as a true representative of the neo-Victorian, politically correct, colour-blind culture of the post-Berlusconian Democratic Party. Her sobriety and security seemed somehow to elude an open conflict and deviate from her first reaction in July $20 \mathrm{I}_{3}$ - 'io non sono di colore, sono nera, e ne sono orgogliosa'. ${ }^{33}$ They seem to express resilience and invisibility - colour blindness - contrasting the hypervisibility into which she is forced: if offences belittle her as a little, black and ugly thing - the female version of the icon Calimero il pulcino nero - the Minister acts her invisibility as a defense strategy. ${ }^{54}$

Kyenge does not refer to herself as black, but as acting in her institutional role that, as such, covers her in a uniform and conceals her race. She pretends to be nothing but the neutral unknowable member of a body (politic): she embodies the raceless, genderless, classless uniform of the State. In this way she can, on the one hand, reconfirm her (supposed) impartial institutional role, stepping back from her (too provocative and not colour-blind enough) initial black-pride statement. On the other hand, her 'lactification' functions as self-defense for a black person who cannot contrast openly racist insults that do nothing but reveal her blackness. In any case, she is pointed at as a 'space invader'. 55

Although her Mammy-like appearance molds her into a more reassuring figure compared to Ruby's, she is requested by the neo-Victorian post-Berlusconian hegemonic culture to rid herself of the Sapphire posture and become the epitome of an unchallenging and silenced multiculturalism. In a sense, if extreme right and xenophobic parties strip her of her voice because of her colour, her own party and neo-Victorian moralism strip her of her voice as a black person, to make her 'one of us'. In both cases, the colonial archive gets re-activated in order to eliminate or neutralize the racialized Other among us.

In conclusion, I used here the figures of the good savage, the little brown victim, the Mammy, the Sapphire, and the Jezebel to understand the re-actualization in Italy of a colonial archive that is nationally as well as transnationally constructed - 'travelling theories', produced, diffused, appropriated, and rearticulated across colonial, imperial locales, and post-colonial 'situations'. ${ }^{6}$ In Italy, the 'colour line' separating the ideal spectator and his/her racialized Others produces the latter as objects of desire as well as repulsion. The anthropophagic scopic regime imposed on the racialized subject by a white hegemonic gaze turns the distanced and silenced authentic Others of AFDK into reassuring good savages: it de-sexualizes and beautifies them as authentic, harmless, inanimate objects.

This same cannibalistic symbolic regime operates differently when the racialized Other corresponds to social and political actors who have a voice and cannot be contained behind the silenced screen produced by the television tourist experience. Kharima Ruby el Mahroug and Cécile Kyenge thus call for a codification of their figures that requires a more radical exercise of that epistemic violence highlighted by Edward Said. This epistemic violence reduces Kyenge to an orangutan as opposed to a contained colour-less member of the political establishment (a Sapphire versus a Mammy), and Ruby to a

\footnotetext{
${ }^{53} \mathrm{http}: / /$ www.repubblica.it/politica/2013/05/03/news/kyenge_nera_non_di_colore_e_fiera_di_esserlo-5796770I/ [accessed 7 August 20I6].

${ }^{54}$ See Lombardi-Diop, 'L'Italia cambia pelle’, pp. II4-I6; Perilli, “"Sesso” e “razza” al muro', pp. II2-I4.

${ }^{55}$ Fanon, p. I7.

${ }^{56}$ On 'travelling theories' see James Clifford, Routes: Travel and Translation in the Late Twentieth Century (Harvard University Press: Harvard, I997). On the concept of 'post-colonial situations' see Sandro Mezzadra, La condizione postcoloniale. Storia e politica nel presente globale (Verona: Ombre corte, 2008).
} 
little black whore versus a brown female victim to be saved (a Jezebel versus an infantilized little girl). The only way to be accepted and then included, within the space of the imagined (racialized) community they have, is to submit themselves to that normalizing white gaze that makes them subaltern, voice-less victims, or accomplices of the Italian white hegemonic society. 